\title{
Nutritional Composition of Culinary Musa ABB at Different Stages of Development
}

\author{
P. Khawas, A. J. Das, N. Sit, L. S. Badwaik, S. C. Deka* \\ Department of Food Engineering and Technology, Tezpur University, Napaam, Assam, India \\ *Corresponding author: sankar@tezu.ernet.in
}

Received March 24, 2014; Revised April 11, 2014; Accepted May 09, 2014

\begin{abstract}
Culinary banana (Musa ABB) is an important ingredient of several dishes and is yet to be scientifically studied its nutritional and other biochemical compositions at different stages of development. It is one of the important nutritionally riches Musa sp and is a part of a balanced diet in Northeast India. Variations in nutritional and biochemical compositions associated with growth were studied at 20 (stage I), 35 (stage II), 50 (stage III), 65 (stage IV) and 80 (stage V) days after emergence (DAE) of banana inflorescence. Ash (7.03 g/100 g), protein (10.56 $\mathrm{g} / 100 \mathrm{~g})$, fat $(1.50 \mathrm{~g} / 100 \mathrm{~g})$, phenol content $(307.99 \mathrm{mg} / 100 \mathrm{~g})$, radical scavenging activity (59.12\% SA), linoleic acid $(2.081 \mathrm{mg} / 100 \mathrm{~g})$ and linolenic acid $(1.210 \mathrm{mg} / 100 \mathrm{~g})$ gradually declined with maturity. A rise in starch content from 12.36 to $22.66 \mathrm{~g} / 100 \mathrm{~g}$ was observed with the maturity of banana. Maximum total carbohydrate was observed at stage III (32.15 g/100 g) and declined gradually. Out of 8 minerals tested, magnesium (Mg) was recorded the highest followed by potassium $(\mathrm{K})$ and zinc $(\mathrm{Zn})$ irrespective of the developmental stages of banana. Essential amino acids were found to be present at all the stages of development. The carotenoids $(0.130-0.159 \mathrm{mg} / 100 \mathrm{~g})$, vitamin A $(0.028-0.038 \mathrm{mg} / 100 \mathrm{~g})$ and thiamine $(0.002-0.032 \mathrm{mg} / 100 \mathrm{~g})$ were recorded at various stages of development of culinary banana. Pulp to peel ratio and total soluble sugars suggest that 50 DAE is the optimum stage of harvesting for culinary banana. However, young stages are rich in antioxidants, amino acids and fatty acids.
\end{abstract}

Keywords: Culinary Musa ABB, biochemical compositions, days after emergence of inflorescence, developmental stages

Cite This Article: P. Khawas, A. J. Das, N. Sit, L. S. Badwaik, and S. C. Deka, "Nutritional Composition of Culinary Musa ABB at Different Stages of Development.” American Journal of Food Science and Technology, vol. 2, no. 3 (2014): 80-87. doi: 10.12691/ajfst-2-3-1.

\section{Introduction}

Banana plants are the world's biggest herbs, grown in many countries. Culinary bananas, often called as plantains, are mostly evolved from the edible varieties of two species Musa acuminata (genome “A”)and Musa balbisiana (genome "B”) (Stover and Simmonds, 1987). Considering the nutritional aspect, plantains and bananas are the world's $4^{\text {th }}$ leading agricultural crop (Ganapathi et al., 1999). Plantains and cooking bananas look almost similar to unripe dessert bananas, but they are larger in size, more fleshy and starchy (Emaga et al., 2008). The cooking type banana is a major staple food in some countries (Seenappa et al., 1986). They are considered to be one of the most important sources of energy and starchy staple food for the people of tropical humid regions (Onwuka and Onwuka, 2005). According to Doymaz (2010) bananas and plantains are rich in nutrients, starch, sugar and vitamins A and C, potassium, calcium, sodium and magnesium. Plantains are nutritionally low protein food material but relatively high in carbohydrates, vitamins and minerals (Offem and Njoku, 1993).

Compared to culinary banana, most available reports are on changes in chemical composition of dessert banana cultivars during ripening (Emaga et al., 2008; Cheirsilp and Umsakul, 2008; Yang and Hoffman, 1984; Marriott et al., 1981).Culinary bananas are rich source of nutrients and the biochemical composition varies with growth stage and maturity (Emagaet al., 2008). The Musa ABB culinary banana (locally called kachkal) found only in Northeast India, and is used as a vegetable in preparing various traditional dishes (Khawas et al., 2014). However, till today no scientific effort has been undertaken for its complete nutritional studies at various stages of development. The nutritional studies will be useful for exploitation of the crop at different stages of growth to obtain value added products. Therefore, the present work was undertaken to study the nutritional and biochemical compositions at various developmental stages of banana Musa ABB which can be exploited for developing value added products.

\section{Methods}

\subsection{Sample Collection and Preparation}

Samples were collected from the experimental plot of Tezpur University, Assam, India. The fingers were harvested at growth stages of 20 days after emergence 
(DAE) (stage I) of banana inflorescence, 35 DAE (stage II), 50 DAE (stage III), 65 DAE (stage IV), and 80 DAE (stage V). Samples were washed thoroughly under running water followed by distilled water and spread out on absorbent tissue papers to remove surface moisture. The pulp and peel samples were separated using a stainless steel knife. The pulp samples were cut into $5 \mathrm{~mm}$ thick slices and dried in a tray drier (IK-112, IKON Instruments, Delhi, India) at $40^{\circ} \mathrm{C}$ for $12 \mathrm{~h}$. Dried samples were ground, sieved and stored at room temperature $\left(25 \pm 2^{\circ} \mathrm{C}\right)$ in air tight containers till the time of analyses.

\subsection{Chemical Analysis}

The initial moisture, ash, protein, and crude fat contents at various stages of development were determined according to methods described in AOAC (2010). Ash content was determined by ignition in a muffle furnace (Optic Ivymen System, SNOL 8, 2/1100, Utena, Lithuania) at $550^{\circ} \mathrm{C}$ for $6 \mathrm{~h}$. Nitrogen content was determined using the Kjeldahl apparatus (KelPlus, Pelican Equipment, Chennai, India) and the amount of nitrogen was multiplied by a factor 6.25. Crude fat was determined using the Soxhlet extractor (Socs Plus, Pelican Equipment, Chennai, India) with n-hexane as solvent. Crude fiber was determined following the acid and alkali treatment as described by Maynard (1970) and Sadasivam and Manikam (2008).The total carbohydrate content was measured by hydrolyzing the polysaccharides (acid hydrolysis) into simple sugars and estimating the resulting monosaccharide by anthrone method (Hodge and Hofreiter, 1962).

The $\mathrm{pH}$ of samples was measured by blending $10 \mathrm{~g}$ of pulp with $40 \mathrm{~mL}$ of deionized water (AOAC, 2010) and the mixture was shaken at 5 min intervals for $15 \mathrm{~min}$ and centrifuged at $3000 \mathrm{rpm}$ for $15 \mathrm{~min}$ in refrigerated centrifuge (SIGMA Laborzentrifugen, 3-18 KS, Osterode, Germany). The supernatant was decanted and determined its pH (pH 510, Eutech, Ayer Rajah Crescent, Singapore). Ascorbic acid and titratable acidity of samples were determined using the method of Ranganna (2008). Cellulose content was estimated by reacting with aceticnitric reagent and measured the absorbance at $630 \mathrm{~nm}$. Lignin content was estimated by extraction in $\mathrm{NaOH}$ solution and aliquot samples were adjusted to $\mathrm{pH} 7.0$ and 12.3. The absorbance of aliquots was measured at 245 and $350 \mathrm{~nm}$. The amount of lignin content was calculated by difference between $A_{245}\left(\mathrm{pH}\right.$ 7.0) and $A_{350}(\mathrm{pH}$ 12.3) (Stafford, 1960).

Starch and amylose contents were determined with the methods of Hodge and Hofreiter (1962) and Sadasivam and Manikam (2008), respectively. Soluble sugars were extracted from $1 \mathrm{~g}$ of sample in $80 \%$ ethanol (hot) and sugar contentwas quantified by the phenol-sulphuric acid method (Dubois et al., 1956). The reducing sugar content was estimated by the Nelson-Somogyi method (Somogyi, 1952). The amount of non-reducing sugars was determined by subtracting the amount of reducing sugars from the amount of total sugars in the sample.

Pectin content was determined by extraction and saponification (Ranganna, 2008) followed by precipitation as calcium pectate by calcium chloride. After removal of chloride ions, the precipitate was dried and weighed. Tannin content was determined by Folin-Denis method
(Schanderi, 1970) in which tannin like compounds reduces phosphotungstomolybdic acid in alkaline solution to produce a densely blue solution, and the intensity was measured spectrophotometrically (Spectrascan UV-2600, Thermo Fisher Scientific, Nasik, India). Phytic acid content was estimated by extracting phytate with trichloroacetic acid and precipitating as ferric salt (Wheeler and Ferrel, 1971).

Total phenolic content was determined with the FolinCiocalteu (F.C.) colorimetric method (Malick and Singh, 1980) where $0.5 \mathrm{~mL}$ extract was mixed with $0.5 \mathrm{~mL}$ F.C. reagent. The contents were mixed by manual shaking for 15-20 s. After $3 \mathrm{~min}, 2 \mathrm{~mL}$ of saturated sodium carbonate solution was added to each tube. The reaction mixturewas placed in a boiling water bath for $1 \mathrm{~min}$, cooled and the absorbance was measured at $650 \mathrm{~nm}$ against deionized water using a dual beam UV-Visible spectrophotometer (Spectrascan UV-2600, Thermo Fisher Scientific, Nasik, India).

The DPPH radical scavenging activity was measured with the method of Brand-Williams et al. (1995) and the assay is based on the ability of antioxidant to scavenge the $\mathrm{DPPH}$ cation radical. This method determines the hydrogen donating capacity of molecule and does not produce oxidative chain reactions or react with free radical intermediates. Scavenging activity (SA) was calculated as per cent inhibition relative to control, using the equation: SA\% $(30 \mathrm{~min})=$ control absorbance at $517 \mathrm{~nm}$ - extract absorbance at $517 \mathrm{~nm} /$ control abs at $517 \mathrm{~nm} \times 100$. Carotenoids were extracted and partitioned in organic solvents on the basis of their solubility. The amount of carotenoids present in the sample was measured spectrophotometrically (Spectrascan UV-2600) at $450 \mathrm{~nm}$ against concentrations of high purity $\beta$-carotene (Sadasivam and Manickam, 2008). Vitamin A content was measured by a rapid colorimetric method of Bayfield and Cole (1980). Thiamine content was estimated by a flurometric method (Sadasivam and Manickam, 2008).

The mineral contents were estimated by inductively coupled plasma optical emission spectrometry (ICP-OES) (Optima 2100 DV, Bridgeport, USA) following the methods of Naozuka et al. (2011). Concentrations were determined in the aqueous solution of acid digest. Powdered samples (1 g) were added to $30 \mathrm{~mL}$ concentrated nitric acid and $5 \mathrm{~mL}$ concentrated hydrochloric acid. The vessels were immediately closed after addition of oxidants. Samples were digested on a hot plate at $100^{\circ} \mathrm{C}$. At the end of the digestion process, digests were cooled and diluted up to $50 \mathrm{~mL}$ with distilled water.

Gas liquid chromatography (GLC) (CP-3800, Varian, USA) was used for analysis of fatty acid profiles. Fatty acids can occur in small amounts in free form, but in general, they are combined in complex molecules through ester or amide bonds. Before GLC analysis non-reactive derivatives of fatty acids methyl esters were prepared (Luddy et al., 1968). Samples were treated with $0.4 \mathrm{~N}$ sodium methylate and shaken vigorously at water bath for 2-3 min at $65^{\circ} \mathrm{C}$ followed by addition of $1 \mathrm{~mL}$ carbon disulphide and shaken for 1-2 min and filtered through activated charcoal. The filtrate constituted all methyl esters of fatty acids and were separated by chromatography (Varian) equipped with a flame ionization detector (FID) and electron capture detector (ECD). The column temperature was $190^{\circ} \mathrm{C}$ and flow of 
the nitrogen carrier gas was maintained at $35 \mathrm{~mL} \cdot \mathrm{min}^{-1}$. Peaks were identified by comparison of retention times to those of standard fatty acid esters.

Amino acid analysis was done by hydrolyzing with $6 \mathrm{~N}$ $\mathrm{HCl}$ and measured by ion exchange chromatography using ninhydrin post-column derivatization. Samples equivalent to $5 \mathrm{mg}$ protein were placed in a $20 \mathrm{~mL}$ glass ampoule, kept on dry ice to avoid clumps forming and $10 \mathrm{~mL} 6 \mathrm{~N}$ $\mathrm{HCl}$ was added. Nitrogen gas was flushed to remove oxygen from the ampoule for 1 min and closed with parafilm. Samples were kept in oven at $110^{\circ} \mathrm{C}$ for $22 \mathrm{~h}$ for hydrolysis. After hydrolysis, samples were removed and allowed to equilibrate at room temperature. The neck of the ampoule was broken and samples transferred to $25 \mathrm{~mL}$ volumetric flasks. Volume was made up to $25 \mathrm{~mL}$ with distilled water and mixed thoroughly and filtered through nitrogen free Whatman No. 1 filter paper. The aliquot (0.5 $\mathrm{mL}$ ) was evaporated at $45-50^{\circ} \mathrm{C}$ and after complete drying, $5 \mathrm{~mL}$ deionized water was added and evaporated again. Drying and evaporation of samples were repeated 4 times. Crude dried samples were dissolved with $2.5 \mathrm{~mL}$ of sodium citrate loading buffer $(\mathrm{pH}$ 2.2). Samples were filtered using a syringe driven filter $(0.45 \mu \mathrm{m})$ and kept in an auto sampler. Standards (100 p mol) and samples were run in an automated amino acid analyzer (Model 119 CL, Beckman, Palo Alto, California).

The colour measurement of samples at different growth stages was analyzed in a Hunter Lab Color Quest (Model Ultrascan Vis-Model, Virginia, USA).

\subsection{Determination of Pulp to Peel Ratio}

Following the method described by Adao and Gloria (2005) the pulp-to-peel ratio was determined by weighing the parts of individual sample in an analytical balance and the results were expressed as percent pulp relative to peel weights.

\subsection{Statistical Analysis}

Experiments were carried out in 4 replicates. The Origin 8.5 (Origin Lab Corporation, Northampton, USA) software was used for statistical analysis. Data were subjected to ANOVA and Fisher's Least Significant Difference (LSD) was used to separate means.

\section{Results and Discussion}

\subsection{Proximate Compositions}

Moisture content (Table 1)decreased gradually from stage I (59.49 g/100 g) to stage III (57.02 g/100 g) and then increased at stages IV (61.07 g/100 g) and V (66.83 $\mathrm{g} / 100 \mathrm{~g})$. There was a significant difference in moisture content in all states except in stages I and II. This might be attributed to respiratory breakdown of starches into sugars and migration of moisture from peel to pulp. Increase in moisture content at stage $\mathrm{V}$ might be due to softening tissue texture as ripening progresses (Onwuka and Onwuka, 2005). An increase of water content in pulp of two cooking banana hybrids with progress in maturity was attributed to utilization of carbohydrates during breathing and osmotic transfer from peel to pulp (Sakyi-Dawson et al., 2008). Ash content decreased as plant's maturity progresses and the highest content was recorded at the stage I (7.03 g/100 g) which decreased gradually at the fully matured stage (3.05 g/100 g). Adeyemi and Oladiji (2009) reported that ash content of ripening plantain is affected by developmental stage and unripe plantain contains higher ash compared to ripe ones. Another reason for variation in ash might be due to differential absorption capacity of minerals at different stages of development. Gradual decrease in protein content as plants matured and decreased from stage I (10.56 g/100 g) to stage V (2.01 g/100 g). Goswami and Borthakur (1996) observed a decline in protein content in culinary banana with maturity and attributed to protein breakdown and the resulting amino acids being utilized in gluconeogenesis. The samples contained a relatively low amount of fat, which varied from stage I (1.50 g/100g) to stage V (0.63 g/100 g) and results are in agreement with Goswami and Borthakur (1996) who reported that fat content $(0.8-1.2 \%)$ in culinary banana was higher during early developmental stages and gradually decreased with increasing maturity. Fiber content also gradually increased as maturity progresses, indicating there were differences due to stage and the highest amount was recorded at stage IV (1.66 g/100 g). Egbebi and Bademosi (2012) reported crude fiber content in unripe and ripe plantain $(0.7-1.11 \%)$ and increased significantly with progress of maturity. The increase in fiber content at matured stage over tender stage might be due to increase in soluble and insoluble dietary fractions. Total carbohydrates content increased from stage I (21.32 g/100 g) to III (32.15 g/100 g) and de creased at stage V (27.63 g/100 g) with significant difference among the stages except in stages III and IV. The variation in carbohydrate contents during growth might be due to degradation of starch for synthesis of sugars (Sakyi-Dawson et al., 2008).

Table 1. Effect of different stages of development on proximate composition of Musa ABB (g/100 g)

\begin{tabular}{|c|c|c|c|c|c|c|}
\hline Stage & Moisture content & Ash & Protein & Fat & Crude fiber & Total carbohydrate \\
\hline I & $59.49 \pm 0.80 b^{\mathrm{a}}$ & $7.03 \pm 0.35^{\mathrm{d}}$ & $10.56 \pm 0.86^{\mathrm{d}}$ & $1.50 \pm 0.11^{\mathrm{d}}$ & $0.61 \pm 0.01^{\mathrm{a}}$ & $21.32 \pm 0.05^{\mathrm{a}}$ \\
\hline II & $55.84 \pm 0.42^{\mathrm{a}}$ & $6.11 \pm 0.73^{\mathrm{c}}$ & $8.61 \pm 0.96^{\mathrm{c}}$ & $1.27 \pm 0.08^{\mathrm{c}}$ & $0.99 \pm 0.08^{\mathrm{b}}$ & $28.04 \pm 0.29^{\mathrm{b}}$ \\
\hline III & $57.02 \pm 0.5^{\mathrm{a}}$ & $4.03 \pm 0.49^{\mathrm{b}}$ & $5.56 \pm 0.84^{\mathrm{c}}$ & $0.94 \pm 0.05^{\mathrm{b}}$ & $1.50 \pm 0.02^{\mathrm{c}}$ & $32.15 \pm 0.20^{\mathrm{d}}$ \\
\hline IV & $61.07 \pm 0.77^{\mathrm{c}}$ & $2.72 \pm 0.20^{\mathrm{a}}$ & $3.99 \pm 0.57^{\mathrm{b}}$ & $0.58 \pm 0.06^{\mathrm{a}}$ & $1.66 \pm 0.05^{\mathrm{d}}$ & $30.93 \pm 0.06^{\mathrm{c}}$ \\
\hline V & $66.83 \pm 1.02^{\mathrm{d}}$ & $3.05 \pm 0.92^{\mathrm{a}}$ & $2.01 \pm 0.87^{\mathrm{a}}$ & $0.63 \pm 0.08^{\mathrm{a}}$ & $0.54 \pm 0.87^{\mathrm{a}}$ & $2^{\mathrm{a}}$ \\
\hline
\end{tabular}

${ }^{\mathrm{a}}$ Means in columns followed by the same letter are not significantly different at $\mathrm{p}<0.05$; values represent mean $\pm \mathrm{SD}, \mathrm{n}=4$

\section{2. pH, Browning Potential and Titratable Acidity}

The $\mathrm{pH}$ (Table 2) was the lowest at stage I (5.01) and highest at stage $\mathrm{V}$ (5.76). A gradual variation in $\mathrm{pH}$ of culinary banana during ripening stages has been reported
(Sakyi-Dawson et al., 2008). Titratable acidity was the lowest during early developmental stage I (0.16 g/100 g) and recorded highest at stage IV (0.32 g/100 g). There was no differences between stages I and II and stages III and V; however, stages II and III were different. Acids play an important role in the post-harvest quality of vegetables, as 
taste is mainly a balance between sugar and acid contents which is important in evaluation of fruit taste (Bainbridge et al., 1996). Sakyi-Dawson et al. (2008) reported changes in titratable acidity and $\mathrm{pH}$ of cooking banana and indicating a general increase in titratable acidity during plantain ripening. Ascorbic acid content (Table 2) varied with stages of development and ranged from $0.74-1.12$ $\mathrm{mg} / 100$ g. Sakyi-Dawson et al. (2008) reported that ascorbic acid content in cooking banana varied with maturity with regular decreasing pattern. The present results are in agreement with the report of Segung and Kader (2000), in case of fluctuation in ascorbic acid content of horticultural crops with maturity. The lowest amount of ascorbic acid in fully matured tomato is reported by Moneruzzaman et al. (2008). Developmental stage affects the cellulose content (Table 2) and the highest value was recorded at stage IV (1.06 mg/100 g). Komolka et al. (2012) reported relatively low amount of cellulose compared to other fruits and vegetables. Lignin content gradually increased with maturity and was the highest at stage IV (1.57 mg/100 g). There was no significant difference between stages I and II; however, differences were observed in stages II, III and IV. This might be due to the lignifications of cell wall constituents resulted an increase in other dietary fiber fractions (Punna and Paruchuri, 2004).

Table 2. Effect of different stages of development on pH, browning potential and titratable acidity of Musa ABB

\begin{tabular}{|c|c|c|c|c|c|}
\hline Stage & $\mathrm{pH}$ & Titratable acidity (g/100g) & Ascorbic acid (mg/100g) & Lignin (mg/100g) & Cellulose (mg/100g) \\
\hline I & $5.03 \pm 0.15 \mathrm{~b}^{\mathrm{a}}$ & $0.16 \pm 0.01^{\mathrm{a}}$ & $1.12 \pm 0.02^{\mathrm{e}}$ & $0.56 \pm 0.08^{\mathrm{a}}$ \\
\hline II & $5.01 \pm 0.09^{\mathrm{a}}$ & $0.19 \pm 0.02^{\mathrm{a}}$ & $0.86 \pm 0.02^{\mathrm{d}}$ & $0.68 \pm 0.10^{\mathrm{a}}$ & $0.04 \pm 0.01^{\mathrm{a}}$ \\
\hline III & $5.12 \pm 0.17^{\mathrm{a}}$ & $0.23 \pm 0.03^{\mathrm{b}}$ & $0.83 \pm 0.03^{\mathrm{c}}$ & $0.25 \pm 0.01^{\mathrm{b}}$ \\
\hline IV & $5.25 \pm 0.37^{\mathrm{a}}$ & $0.32 \pm 0.02^{\mathrm{c}}$ & $0.91 \pm 0.11^{\mathrm{b}}$ & $0.32 \pm 0.02^{\mathrm{c}}$ \\
\hline V & $5.76 \pm 0.87^{\mathrm{b}}$ & $0.25 \pm 0.05^{\mathrm{b}}$ & $0.74 \pm 0.90^{\mathrm{a}}$ & $1.57 \pm 0.02^{\mathrm{c}}$ \\
\hline
\end{tabular}

${ }^{\mathrm{a}}$ Means in columns followed by the same letter are not significantly different at $\mathrm{p}<0.05$; values represent mean \pm SD, $\mathrm{n}=4$

\subsection{Starch, Amylose, Sugar and Pectin Contents}

Starch, amylose and sugar contents varied with maturity (Table 3). Present study revealed that starch is the major storage form of carbohydrates in cooking bananas. The starch content increased from stage I (12.36 g/100 g) to stage III (22.66 g/100 g) and then declined at stage V (11.21 g/100 g). Starch accumulation led to the higher weight in matured plantain (Kudachikar et al., 2004). Carbohydrate in the form of starch is the major chemical change which occurs throughout growth and development in cooking bananas and plantains (Sakyi-Dawson et al., 2008). Amylose content was affected by stages of development and increased from stage I to stage IV (3.77 to $8.81 \mathrm{~g} / 100 \mathrm{~g})$ with maturity. An increase in total carbohydrates content might be correlated with active synthesis of starch with growth however, with maturity of cooking banana starch content decreased and total soluble sugars increased significantly. Marriott et al.(1981) also reported similar results in ripening banana and plantains. Total soluble sugars content (Table 3) increased very marginally from stage I $(0.64 \mathrm{~g} / 100 \mathrm{~g})$ to stage III (1.35 $\mathrm{g} / 100 \mathrm{~g})$ and thereafter sharp increase from stage IV (2.01 $\mathrm{g} / 100 \mathrm{~g})$ and in stage $\mathrm{V}$ (4.65 g/100 g) and this evinces that starch degrades with more maturity. Ogazi (1996) reported that sugars comprise only about $1.30 \mathrm{~g} / 100 \mathrm{~g}$ of total drymatter in unripe plantain which corroborates the present findings. Reducing and nonreducing sugars (Table 3) increased with maturity. Nonreducing sugars (0.37$3.72 \mathrm{~g} / 100 \mathrm{~g})$ was higher than reducing sugars (0.16 $1.08 \mathrm{~g} / 100 \mathrm{~g})$. Sakyi-Dawson et al. (2008) reported a similar trend of nonreducing sugar contents in plantain and cooking banana. There was significant difference in pectin content among stages and it increased from stage I (0.92 $\mathrm{mg} / 100 \mathrm{~g})$ to stage III $(1.37 \mathrm{mg} / 100 \mathrm{~g})$ which thereafter declined at stage $\mathrm{V}(0.81 \mathrm{mg} / 100 \mathrm{~g})$. The reason for increase in pectin content with the advancement of growth up to stage III might be due to less interaction between the pectin and the other cellular components and as a consequence the pectin was more available for extraction. On the other hand, decrease at stage IV and V might be due to the degradation of pectin under the action of pecticenzymes, such as polygalacturonase (PG), pectin methyl esterase (PME) or pectatelyase (PL). The increase of pectin content up to a certain stage and then decrease was also observed by Lohani et al. (2004).

Table 3. Effect of different stages of development on starch, amylose, total soluble, reducing, nonreducing sugars and pectin content of Musa ABB

\begin{tabular}{|c|c|c|c|c|c|}
\hline Stage & $\begin{array}{c}\text { Starch (g/100 } \\
\text { g) }\end{array}$ & $\begin{array}{c}\text { Amylose }(\mathrm{g} / 100 \\
\mathrm{g})\end{array}$ & $\begin{array}{c}\text { Total soluble sugars } \\
(\mathrm{g} / 100 \mathrm{~g})\end{array}$ & $\begin{array}{c}\text { Reducing sugars } \\
(\mathrm{g} / 100 \mathrm{~g})\end{array}$ & $\begin{array}{c}\text { Nonreducing sugars } \\
(\mathrm{g} / 100 \mathrm{~g})\end{array}$ \\
\hline I & $12.36 \pm 0.17 \mathrm{a}^{\mathrm{a}}$ & $3.77 \pm 0.51^{\mathrm{a}}$ & $0.64 \pm 0.03^{\mathrm{a}}$ & $0.16 \pm 0.02^{\mathrm{a}}$ & $0.37 \pm 0.08^{\mathrm{a}}$ \\
\hline II & $18.47 \pm 0.10^{\mathrm{b}}$ & $5.84 \pm 0.48^{\mathrm{b}}$ & $0.72 \pm 0.05^{\mathrm{b}}$ & $0.29 \pm 0.06^{\mathrm{b}}$ & $0.92 \pm 0.15^{\mathrm{a}}$ \\
\hline III & $22.66 \pm 0.61^{\mathrm{c}}$ & $7.25 \pm 0.62^{\mathrm{c}}$ & $1.35 \pm 0.03^{\mathrm{c}}$ & $0.41 \pm 0.01^{\mathrm{c}}$ & $0.48 \pm 0.04^{\mathrm{b}}$ \\
\hline IV & $20.32 \pm 0.99^{\mathrm{d}}$ & $8.81 \pm 0.52^{\mathrm{d}}$ & $2.01 \pm 0.06^{\mathrm{d}}$ & $0.54 \pm 0.04^{\mathrm{d}}$ & $0.63 \pm 0.01^{\mathrm{c}}$ \\
\hline V & $11.21 \pm 0.9^{5}$ & $6.65 \pm 0.75^{\mathrm{b}}$ & $4.65 \pm 0.97^{\mathrm{e}}$ & $1.27 \pm 0.10^{\mathrm{b}}$ & $1.37 \pm 0.05^{\mathrm{b}}$ \\
\hline
\end{tabular}

${ }^{\mathrm{a}}$ Means in columns followed by the same letter are not significantly different at $\mathrm{p}<0.05$; values represent mean \pm SD, $\mathrm{n}=4$

Table 4. Effect of different stages of development on tannin and phytic acid content of Musa ABB

\begin{tabular}{|c|c|c|}
\hline Stage & Tannin (mg/100 g) & Phytic acid (mg/100 g) \\
\hline I & $0.59 \pm 0.01^{\mathrm{e}}$ & $15.50 \pm 0.39^{\mathrm{b}}$ \\
\hline II & $0.51 \pm 0.02^{\mathrm{d}}$ & $24.15 \pm 0.95^{\mathrm{e}}$ \\
\hline III & $0.34 \pm 0.06^{\mathrm{c}}$ & $20.05 \pm 1.50^{\mathrm{d}}$ \\
\hline IV & $0.27 \pm 0.03^{\mathrm{b}}$ & $18.88 \pm 0.97^{\mathrm{c}}$ \\
\hline V & $0.21 \pm 0.06^{\mathrm{a}}$ & $11.96 \pm 1.05^{\mathrm{a}}$ \\
\hline
\end{tabular}

${ }^{a}$ Means in columns followed by the same letters are not significantly different at $\mathrm{p}<0.05$; values represent mean $\pm \mathrm{SD}, \mathrm{n}=4$

\subsection{Tannin and Phytic Acid Contents}

The tannin content (Table 4) of samples differed significantly with stages of development and the highest amount was recorded at stage I (0.59 mg/100 g) which declined with maturity $(0.21 \mathrm{mg} / 100 \mathrm{~g})$. The decrease in tannin content with advancement of growth reduces the astringency property. Mendoza et al.(1992) reported the tannin content in cooking bananas of Philippians (1.03$5.66 \mathrm{mg}$ tannic acid equivalent/g) which is relatively 
higher than the present values. As culinary banana attains maturity the astringency property gets reduced which is related to insolubilization and polymerization of polyphenols with other constituents of pulp. The variation might be due to differences in cultivar, growth condition and environmental factors. Fruits and vegetables normally exhibit astringency when it is young and gradually losses this characteristic property with maturity and becomes palatable for exploitation (Mendoza et al., 1992). The stages of development also affect phytic acid content (Table 4) and recorded the highest values at stage II (24.15 mg/100 g) and lowest at stage V (11.96 mg/100 g). The amount of phytic acid was low compared to other starchy foods like cassava (95-135 mg/g) (Charles et al., 2005).

\subsection{Total Polyphenols, DPPH Radical Scavenging Activity, Total Carotenoids, Vitamin $A$ and Thiamine Contents}

Wide variations in total polyphenols (91.87 - $307.99 \mathrm{mg}$ GAE/100 g dry matter), DPPH radical scavenging activity
(39.64 - $59.12 \%$ SA), total carotenoids (0.130 - 0.159 $\mathrm{mg} / 100 \mathrm{~g})$, vitamin A (0.029 - $0.038 \mathrm{mg} / 100 \mathrm{~g})$ and thiamine $(0.019-0.032 \mathrm{mg} / 100 \mathrm{~g})$ contents at different stages of development were observed (Table 5). Total polyphenols were found higher at stage I compared to the other stages. Bananas have been classified as one of the prominent antioxidant foods by Kanazawa and Sakakibara (2000). The highest DPPH radical scavenging activity was observed in stage I and lowest at stage $\mathrm{V}$ and it decreased with maturity. Decreasing trend in scavenging activity of papaya with respect to crop maturity was also observed by Zuhair et al. (2013). A gradual increase in total carotenoids, vitamin A from stage I to stage $\mathrm{V}$ was observed and recorded the highest at stage $\mathrm{V}$. Increase in thiamine content up to stage IV was observed but declined at stage $\mathrm{V}$. Total carotenoid contents in fruits and vegetables increases during ripening because the chlorophyll undergoes degradation and carotenogenesis takes place resulting in synthesis of greater amount of individual carotenoid compounds at chromoplast rather than the chloroplast (Gross, 1991).

Table 5. Effect of different stages of development on total polyphenols, DPPH radical scavenging activity, total carotenoids, vitamin A and thiamine contents of Musa ABB

\begin{tabular}{|c|c|c|c|c|c|}
\hline Stage & $\begin{array}{c}\text { Total polyphenols (mg GAE/100 g } \\
\text { dry matter }^{\text {a }} \text { ) }\end{array}$ & $\begin{array}{c}\text { DPPH radical scavenging } \\
\text { activity (\% SA) }\end{array}$ & $\begin{array}{l}\text { Total carotenoids } \\
(\mathrm{mg} / 100 \mathrm{~g})\end{array}$ & $\begin{array}{l}\text { Vitamin A } \\
(\mathrm{mg} / 100 \mathrm{~g})\end{array}$ & $\begin{array}{l}\text { Thiamine } \\
\text { (mg/100 g) }\end{array}$ \\
\hline I & $307.99 \pm 2.86 \mathrm{e}^{\mathrm{b}}$ & $59.12 \pm 0.73^{\mathrm{d}}$ & $0.130 \pm 0.07^{\mathrm{a}}$ & $0.029 \pm 0.01^{\mathrm{a}}$ & $0.002 \pm 0.01^{\mathrm{a}}$ \\
\hline II & $261.22 \pm 2.29^{\mathrm{d}}$ & $55.60 \pm 1.16^{\mathrm{c}}$ & $0.142 \pm 0.05^{b}$ & $0.028 \pm 0.03^{\mathrm{a}}$ & $0.019 \pm 0.01^{\mathrm{b}}$ \\
\hline III & $178.72 \pm 2.60^{c}$ & $52.66 \pm 2.47^{c}$ & $0.147 \pm 0.01^{\mathrm{c}}$ & $0.030 \pm 0.02^{\mathrm{a}}$ & $0.027 \pm 0.03 c$ \\
\hline IV & $160.96 \pm 2.40^{\mathrm{b}}$ & $46.96 \pm 4.20^{\mathrm{b}}$ & $0.153 \pm 0.09^{d}$ & $0.033 \pm 0.02^{b}$ & $0.032 \pm 0.03^{\mathrm{d}}$ \\
\hline $\mathrm{V}$ & $91.87 \pm 2.07^{\mathrm{a}}$ & $39.64 \pm 1.75^{\mathrm{a}}$ & $0.159 \pm 0.02^{\mathrm{e}}$ & $0.038 \pm 0.01^{\mathrm{c}}$ & $0.021 \pm 0.07^{b}$ \\
\hline
\end{tabular}

${ }^{\mathrm{a}} \mathrm{GAE}=$ gallic acid equivalent.

${ }^{\mathrm{b}}$ Means in each column followed by the same letters are not significantly different at $\mathrm{p}<0.05$; Values represent mean $\pm \mathrm{SD}$, $\mathrm{n}=4$.

\subsection{Minerals Content}

Results of mineral contents are presented in Table 6 . Out of all the minerals $\mathrm{Mg}$ was recorded the highest (0.961 - $1.183 \mathrm{mg} / 100 \mathrm{~g})$ in all stages with significant difference. The highest concentrations of $\mathrm{Fe}(0.385$ $\mathrm{mg} / 100 \mathrm{~g}), \mathrm{Cu}$ (0.009 mg/100 g), and Ca (0.542 mg/100 g) were recorded at stage II; however, Zn concentration recorded the highest $(0.417 \mathrm{mg} / 100 \mathrm{~g})$ at stage IV. Significant variations of K (0.498 - $1.273 \mathrm{mg} / 100 \mathrm{~g})$, Ca
(0.241 - $0.542 \mathrm{mg} / 100 \mathrm{~g}), \mathrm{Fe}(0.173-0.385 \mathrm{mg} / 100 \mathrm{~g})$ and $\mathrm{Na}(0.115-0.167 \mathrm{mg} / 100 \mathrm{~g})$ were observed at all stages of development. The variation in mineral contents at the growth stages is mainly attributed to preferential absorbance and this might be due to cultivar and/or soil, climate, agricultural practice and the quality of water for irrigation (Rop et al., 2010). Most of the minerals are very crucial in many enzymes activities, protecting cells from free radicals attack, regulation of glucose homeostasis etc. (Garget al., 2005; Anhwange, 2008).

Table 6. Effect of different stages of development on mineral contents of Musa ABB (mg/100g)

\begin{tabular}{|c|c|c|c|c|c|c|c|c|}
\hline Stage & $\mathrm{Na}$ & $\mathrm{K}$ & $\mathrm{Fe}$ & $\mathrm{Cu}$ & $\mathrm{Mn}$ & $\mathrm{Zn}$ & $\mathrm{Mg}$ & $\mathrm{Ca}$ \\
\hline I & $0.115 \pm 0.87^{\mathrm{a}}$ & $0.889 \pm 0.75^{\mathrm{c}}$ & $0.302 \pm 0.91 d^{a}$ & $0.008 \pm 0.01^{\mathrm{a}}$ & $0.005 \pm 0.27^{\mathrm{a}}$ & $0.350 \pm 0.04^{b}$ & $0.961 \pm 0.65^{\mathrm{a}}$ & $0.432 \pm 3.11^{\mathrm{d}}$ \\
\hline II & $0.127 \pm 1.34^{b}$ & $1.038 \pm 0.98^{\mathrm{d}}$ & $0.385 \pm 1.71^{\mathrm{e}}$ & $0.009 \pm 0.31^{\mathrm{e}}$ & $0.013 \pm 0.66^{\mathrm{c}}$ & $0.389 \pm 1.09^{\mathrm{d}}$ & $1.020 \pm 1.71^{\mathrm{c}}$ & $0.542 \pm 4.92^{\mathrm{e}}$ \\
\hline III & $0.139 \pm 1.28^{c}$ & $1.273 \pm 0.97^{\mathrm{e}}$ & $0.210 \pm 0.46^{\mathrm{b}}$ & $0.005 \pm 0.03^{\mathrm{d}}$ & $0.014 \pm 0.16^{\mathrm{d}}$ & $0.353 \pm 1.50^{c}$ & $1.183 \pm 0.37^{\mathrm{e}}$ & $0.345 \pm 6.56^{\mathrm{c}}$ \\
\hline IV & $0.167 \pm 0.99^{\mathrm{e}}$ & $0.723 \pm 0.96^{\mathrm{b}}$ & $0.240 \pm 1.25^{\mathrm{c}}$ & $0.004 \pm 0.03^{\mathrm{c}}$ & $0.017 \pm 0.32^{\mathrm{e}}$ & $0.417 \pm 1.28^{\mathrm{e}}$ & $1.109 \pm 0.19^{\mathrm{d}}$ & $0.274 \pm 2.03^{b}$ \\
\hline $\mathrm{V}$ & $0.164 \pm 1.29^{\mathrm{d}}$ & $0.498 \pm 0.98^{\mathrm{a}}$ & $0.173 \pm 1.05^{\mathrm{a}}$ & $0.002 \pm 0.06^{b}$ & $0.011 \pm 0.89^{b}$ & $0.312 \pm 1.75^{\mathrm{a}}$ & $1.024 \pm 0.96^{b}$ & $0.241 \pm 3.67^{\mathrm{a}}$ \\
\hline
\end{tabular}

${ }^{\mathrm{a}}$ Means in each column followed by the same letters are not significantly different at $\mathrm{p}<0.05$; values represent mean \pm SD, $\mathrm{n}=4$.

\subsection{Fatty Acids Composition}

Results (Table 7) revealed that the major saturated fatty acids are palmitic acid $(0.267-1.678 \mathrm{mg} / 100 \mathrm{~g})$ and stearic acid (0.061 - $0.091 \mathrm{mg} / 100 \mathrm{~g})$. The palmitic acid content decreased from stage I to stage $\mathrm{V}$ whereas stearic acid decreased from stage I to stage III and was absent at subsequent stages. Lauric (0.006 - $0.092 \mathrm{mg} / 100 \mathrm{~g})$ and myristic (0.008 - $0.019 \mathrm{mg} / 100 \mathrm{~g})$ acids were recorded in minor quantities during early stages of development, which gradually decreased towards maturity. Among unsaturated fatty acids the most predominant were linoleic (0.329 - $2.081 \mathrm{mg} / 100 \mathrm{~g})$ and linolenic acids (0.139 -
$1.210 \mathrm{mg} / 100 \mathrm{~g})$. These essential fatty acids were the highest during early developmental stages. The oleic acid (0.128 - $0.651 \mathrm{mg} / 100 \mathrm{~g}$ ) was recorded the highest at stage II and it indicates involvement of lipids to metabolic changes during development. The linoleic acid has nutritional benefits due to its metabolism at tissue levels which produces hormone like compound prostaglandins (Ramadan and Morsel, 2002). The role of $\alpha$-linolenic acid has been reported in disease prevention (Simopoulos, 1999). The early rise in linoleic acid appeared to be associated with glycolipid and is a unique component in chloroplast of young plantains. Presence of these 
unsaturated fatty acids in a reasonable amount enhances nutritional value of this crop.

Table 7. Effect of different stages of development on fatty acid (mg/100g) profile of Musa ABB

\begin{tabular}{|c|c|c|c|c|c|c|c|c|}
\hline Stage & Lauric acid & Myristic acid & Palmitic acid & Palmitoleic acid & Stearic acid & Oleic acid & Linoleic acid & Linolenic acid \\
\hline $\mathrm{I}$ & $0.013 \pm 1.54 b^{a}$ & $0.019 \pm 0.97^{b}$ & $1.678 \pm 1.52^{\mathrm{e}}$ & $0.059 \pm 1.22^{\mathrm{b}}$ & $0.091 \pm 0.82^{c}$ & $0.128 \pm 10.51^{\mathrm{a}}$ & $2.081 \pm 8.49^{\mathrm{e}}$ & $1.210 \pm 10.91^{\mathrm{d}}$ \\
\hline II & $0.006 \pm 1.01^{\mathrm{b}}$ & $0.008 \pm 0.50^{\mathrm{a}}$ & $0.988 \pm 1.84^{\mathrm{d}}$ & $0.027 \pm 0.53^{\mathrm{a}}$ & $0.061 \pm 0.81^{\mathrm{a}}$ & $0.651 \pm 6.1^{\mathrm{c}}$ & $1.386 \pm 5.39^{d}$ & $0.670 \pm 11.66^{\mathrm{C}}$ \\
\hline III & $0.092 \pm 1.04^{\mathrm{c}}$ & $0.013 \pm 1.41^{\mathrm{c}}$ & $0.593 \pm 1.32^{c}$ & ND & $0.068 \pm 1.18^{b}$ & $0.524 \pm 6.76^{\mathrm{b}}$ & $0.387 \pm 6.05^{b}$ & $0.139 \pm 5.16^{\mathrm{a}}$ \\
\hline IV & $\mathrm{ND}^{1}$ & ND & $0.422 \pm 0.37^{\mathrm{b}}$ & ND & ND & ND & $0.603 \pm 7.58^{\mathrm{c}}$ & $0.213 \pm 6.30^{\mathrm{b}}$ \\
\hline V & ND & ND & $0.267 \pm 0.75^{\mathrm{a}}$ & ND & ND & ND & $0.329 \pm 3.76^{\mathrm{a}}$ & ND \\
\hline
\end{tabular}

${ }^{\mathrm{a}}$ Means in columns followed by the same letters are not significantly different at $\mathrm{p}<0.05$; values represent mean \pm SD, $\mathrm{n}=4$.

${ }^{1} \mathrm{ND}=$ Not detected.

\subsection{Amino Acids Composition}

Results (Table 8) revealed that all the essential amino acids viz., histidine, isoleucine, leucine, lysine, methionine, phenylalanine, threonine, tryptophan and valine are present in the culinary banana. Amino acids content decreased from stage $\mathrm{I}$ to stage $\mathrm{V}$ of growth and development (Table 8) of culinary banana. The predominant amino acids are glutamic acid (0.75 - 3.12 g/100 g), aspartic acid (0.05 - $1.08 \mathrm{~g} / 100 \mathrm{~g})$ and alanine (0.19 - $0.45 \mathrm{~g} / 100 \mathrm{~g})$ and declined with maturity. Deka and Harmine (1997) also reported the presence of all the essential and non-essential, amino acids in cultivar: Borjahaji (AAA) banana. The limiting amino acid methionine (0.017 - $0.048 \mathrm{~g} / 100 \mathrm{~g}$ ) was recorded in fewer amounts as compared to other amino acids. In plants ethylene plays a key role in fruit ripening and it is synthesized from methionine (Yang and Hoffman, 1984). There is a marked variation in most of the amino acid contents among all stages except for proline, leucine, tyrosine and phenylalanine. Decrease in amino acids level with advancement in maturity has been previously reported in tomato (Sorrequieta et al., 2013).

\begin{tabular}{|c|c|c|c|c|c|c|c|c|c|c|c|c|c|c|c|c|c|c|}
\hline $\begin{array}{l}\text { St } \\
\text { ag } \\
\mathrm{e}\end{array}$ & $\begin{array}{l}\text { Trypt } \\
\text { ophan }\end{array}$ & $\begin{array}{l}\text { Asp } \\
\text { artic } \\
\text { acid }\end{array}$ & $\begin{array}{l}\text { Thre } \\
\text { onine }\end{array}$ & $\begin{array}{l}\text { Ser } \\
\text { ine }\end{array}$ & $\begin{array}{l}\text { Glut } \\
\text { amic } \\
\text { acid }\end{array}$ & $\begin{array}{l}\text { Prol } \\
\text { ine }\end{array}$ & $\begin{array}{l}\text { Gly } \\
\text { cine }\end{array}$ & $\begin{array}{l}\text { Ala } \\
\text { nine }\end{array}$ & $\begin{array}{l}\text { Cys } \\
\text { tine }\end{array}$ & $\begin{array}{l}\text { Val } \\
\text { ine }\end{array}$ & $\begin{array}{l}\text { Methi } \\
\text { onine }\end{array}$ & $\begin{array}{l}\text { Isole } \\
\text { ucine }\end{array}$ & $\begin{array}{l}\text { Leu } \\
\text { cine }\end{array}$ & $\begin{array}{l}\text { Tyro } \\
\text { sine }\end{array}$ & $\begin{array}{l}\text { Phe } \\
\text { nyl } \\
\text { ala } \\
\text { nin } \\
\text { e }\end{array}$ & $\begin{array}{l}\text { Histi } \\
\text { dine }\end{array}$ & $\begin{array}{l}\text { Lys } \\
\text { ine }\end{array}$ & $\begin{array}{l}\text { Argi } \\
\text { nine }\end{array}$ \\
\hline I & $\begin{array}{l}0.16 \pm \\
0.04^{\mathrm{b}}\end{array}$ & $\begin{array}{c}1.08 \\
\pm \\
0.01 \\
\mathrm{~d}\end{array}$ & $\begin{array}{c}0.29 \pm \\
0.02^{\mathrm{e}}\end{array}$ & $\begin{array}{c}0.4 \\
3 \pm \\
0.6 \\
1^{\mathrm{d}}\end{array}$ & $\begin{array}{c}3.12 \\
\pm \\
0.31^{\mathrm{e}}\end{array}$ & $\begin{array}{c}0.2 \\
0 \pm \\
0.0 \\
3^{\mathrm{c}}\end{array}$ & $\begin{array}{c}0.37 \\
\pm \\
0.55 \\
d\end{array}$ & $\begin{array}{c}0.45 \\
\pm \\
0.06 \\
\mathrm{e}\end{array}$ & $\begin{array}{c}0.03 \\
\pm \\
0.41 \\
\mathrm{~b}\end{array}$ & $\begin{array}{l}0.4 \\
2 \pm \\
0.0 \\
7^{\mathrm{d}}\end{array}$ & $\begin{array}{c}0.047 \\
\pm \\
0.01^{\mathrm{c}}\end{array}$ & $\begin{array}{l}0.30 \pm \\
0.51^{\mathrm{d}}\end{array}$ & $\begin{array}{c}0.58 \\
\pm \\
0.99 \\
\mathrm{~b}\end{array}$ & $\begin{array}{c}0.14 \\
\pm \\
0.03^{\mathrm{c}}\end{array}$ & $\begin{array}{c}0.3 \\
6 \pm \\
0.0 \\
5^{b}\end{array}$ & $\begin{array}{c}0.31 \\
\pm \\
0.05^{\mathrm{d}}\end{array}$ & $\begin{array}{c}0.3 \\
5 \pm \\
0.0 \\
8^{a}\end{array}$ & $\begin{array}{c}0.45 \\
\pm \\
0.90^{\mathrm{e}}\end{array}$ \\
\hline II & $\begin{array}{c}0.17 \pm \\
0.22^{\mathrm{b}}\end{array}$ & $\begin{array}{c}1.02 \\
\pm \\
0.09 \\
\text { c }\end{array}$ & $\begin{array}{c}0.26 \pm \\
0.04^{\mathrm{c}}\end{array}$ & $\begin{array}{c}0.3 \\
8 \pm \\
0.7 \\
0^{c}\end{array}$ & $\begin{array}{c}3.01 \\
\pm \\
0.06^{\mathrm{d}}\end{array}$ & $\begin{array}{c}0.1 \\
7 \pm \\
0.0 \\
3^{\mathrm{b}}\end{array}$ & $\begin{array}{c}0.33 \\
\pm \\
0.62 \\
\text { c }\end{array}$ & $\begin{array}{c}0.41 \\
\pm \\
0.05 \\
\mathrm{c}\end{array}$ & $\begin{array}{c}0.04 \\
\pm \\
0.11 \\
\mathrm{c}\end{array}$ & $\begin{array}{l}0.3 \\
8 \pm \\
0.0 \\
7^{c}\end{array}$ & $\begin{array}{c}0.048 \\
\pm \\
0.02^{\mathrm{c}}\end{array}$ & $\begin{array}{l}0.27 \pm \\
0.55^{b}\end{array}$ & $\begin{array}{c}0.62 \\
\pm \\
0.67 \\
\mathrm{c}\end{array}$ & $\begin{array}{c}0.13 \\
\pm \\
0.02 \\
\mathrm{~b}\end{array}$ & $\begin{array}{c}0.4 \\
1 \pm \\
0.0 \\
3^{\mathrm{c}}\end{array}$ & $\begin{array}{c}0.24 \\
\pm \\
0.05^{\mathrm{c}}\end{array}$ & $\begin{array}{c}0.4 \\
7 \pm \\
0.0 \\
4^{\mathrm{c}}\end{array}$ & $\begin{array}{c}0.40 \\
\pm \\
0.75 \\
\mathrm{~d}\end{array}$ \\
\hline III & $\begin{array}{c}0.19 \pm \\
0.02^{\mathrm{c}}\end{array}$ & $\begin{array}{c}0.73 \\
\pm \\
0.01 \\
2^{\mathrm{b}}\end{array}$ & $\begin{array}{c}0.28 \pm \\
0.04^{\mathrm{d}}\end{array}$ & $\begin{array}{c}0.4 \\
6 \pm \\
0.4 \\
3^{\mathrm{e}}\end{array}$ & $\begin{array}{c}1.95 \\
\pm \\
0.33^{\mathrm{c}}\end{array}$ & $\begin{array}{c}0.1 \\
2 \pm \\
0.0 \\
4^{\mathrm{a}}\end{array}$ & $\begin{array}{c}0.31 \\
\pm \\
0.46 \\
b\end{array}$ & $\begin{array}{c}0.44 \\
\pm \\
0.06 \\
d\end{array}$ & $\begin{array}{c}0.02 \\
\pm \\
0.15 \\
a\end{array}$ & $\begin{array}{c}0.4 \\
3 \pm \\
0.0 \\
4^{\mathrm{e}}\end{array}$ & $\begin{array}{c}0.035 \\
\pm \\
0.03^{\mathrm{b}}\end{array}$ & $\begin{array}{c}0.29 \pm \\
0.95^{\mathrm{c}}\end{array}$ & $\begin{array}{c}0.69 \\
\pm \\
0.58 \\
\mathrm{e}\end{array}$ & $\begin{array}{c}0.13 \\
\pm \\
0.02 \\
\mathrm{~b}\end{array}$ & $\begin{array}{c}0.4 \\
2 \pm \\
0.0 \\
4^{\mathrm{d}}\end{array}$ & $\begin{array}{c}0.19 \\
\pm \\
0.03^{b}\end{array}$ & $\begin{array}{c}0.5 \\
6 \pm \\
0.0 \\
5^{d}\end{array}$ & $\begin{array}{c}0.35 \\
\pm \\
0.55 \\
\mathrm{~b}\end{array}$ \\
\hline IV & $\begin{array}{l}0.31 \pm \\
0.65^{d}\end{array}$ & $\begin{array}{c}0.05 \\
\pm \\
0.02 \\
\mathrm{a}\end{array}$ & $\begin{array}{l}0.23 \pm \\
0.02^{b}\end{array}$ & $\begin{array}{c}0.2 \\
7 \pm \\
0.2 \\
5^{b}\end{array}$ & $\begin{array}{c}1.22 \\
\pm \\
0.95^{\mathrm{b}}\end{array}$ & $\begin{array}{c}0.1 \\
3 \pm \\
0.4 \\
5^{\mathrm{a}}\end{array}$ & $\begin{array}{c}0.30 \\
\pm \\
0.41 \\
\mathrm{a}\end{array}$ & $\begin{array}{c}0.32 \\
\pm \\
0.06 \\
\mathrm{~b}\end{array}$ & $\begin{array}{c}0.03 \\
\pm \\
0.62 \\
\mathrm{~b}\end{array}$ & $\begin{array}{c}0.3 \\
4 \pm \\
0.0 \\
6^{b}\end{array}$ & $\begin{array}{c}0.021 \\
\pm \\
0.01^{\mathrm{a}}\end{array}$ & $\begin{array}{c}0.23 \pm \\
0.49^{\mathrm{a}}\end{array}$ & $\begin{array}{c}0.65 \\
\pm \\
0.86 \\
d\end{array}$ & $\begin{array}{c}0.09 \\
\pm \\
0.02^{\mathrm{a}}\end{array}$ & $\begin{array}{c}0.4 \\
3 \pm \\
0.0 \\
5^{\mathrm{e}}\end{array}$ & $\begin{array}{c}0.12 \\
\pm \\
0.02^{\mathrm{a}}\end{array}$ & $\begin{array}{c}0.6 \\
3 \pm \\
0.0 \\
5^{\mathrm{e}}\end{array}$ & $\begin{array}{c}0.38 \\
\pm \\
0.68^{\mathrm{c}}\end{array}$ \\
\hline $\mathrm{V}$ & $\begin{array}{c}0.10 \pm \\
0.28^{\mathrm{a}}\end{array}$ & N.D & $\begin{array}{c}0.15 \pm \\
0.01^{\mathrm{a}}\end{array}$ & $\begin{array}{c}0.2 \\
0 \pm \\
0.2 \\
4^{\mathrm{a}}\end{array}$ & $\begin{array}{c}0.75 \\
\pm \\
0.03^{\mathrm{a}}\end{array}$ & $\begin{array}{l}\text { N. } \\
\text { D }\end{array}$ & N.D & $\begin{array}{c}0.19 \\
\pm \\
0.11 \\
\mathrm{a}\end{array}$ & N.D & $\begin{array}{c}0.1 \\
6 \pm \\
0.0 \\
2^{\mathrm{a}}\end{array}$ & $\begin{array}{c}0.017 \\
\pm \\
0.01^{\mathrm{a}}\end{array}$ & N.D & $\begin{array}{c}0.44 \\
\pm \\
0.52 \\
\mathrm{a}\end{array}$ & N.D & $\begin{array}{l}0.3 \\
2 \pm \\
0.0 \\
6 a\end{array}$ & N.D & $\begin{array}{c}0.4 \\
1 \pm \\
0.0 \\
8^{b}\end{array}$ & $\begin{array}{c}0.27 \\
\pm \\
0.75^{\mathrm{a}}\end{array}$ \\
\hline
\end{tabular}

${ }^{\mathrm{a}}$ Means in columns followed by the same letters are not significantly different at $\mathrm{p}<0.05$; values represent mean \pm SD, $\mathrm{n}=4$.

\subsection{Colour Measurement}

The degree of lightness and yellowness increased with maturity but the degree of redness followed a decreasing trend (Table 9). The increase in degree of lightness with maturity might be attributed to reduction in browning potential with growth. Change in colour of the culinary banana is the major physical and chemical changes with the approach of maturation. This could be attributed to degradation of chlorophyll coupled with synthesis of other plant pigments usually carotenoids and anthocyanin. Therefore an increase in yellowness in fully matured culinary banana is associated with increase in total carotenoid content. Several studies have revealed that change in fruit colour is an important indicator to identify stage of crop maturity physically (Soltani et al., 2011).
Table 9. Effect of different stages of development on colour measurement of Musa ABB

\begin{tabular}{|c|c|c|c|}
\hline Stage & L & a & b \\
\hline I & $47.04 \pm 1.24 a^{\mathrm{a}}$ & $2.87 \pm 0.04^{\mathrm{e}}$ & $6.49 \pm 0.05^{\mathrm{a}}$ \\
\hline II & $60.62 \pm 1.12^{\mathrm{b}}$ & $2.19 \pm 0.03^{\mathrm{d}}$ & $7.79 \pm 0.12^{\mathrm{b}}$ \\
\hline III & $70.31 \pm 1.35^{\mathrm{d}}$ & $2.04 \pm 0.03^{\mathrm{c}}$ & $8.29 \pm 0.08^{\mathrm{c}}$ \\
\hline IV & $69.06 \pm 2.28^{\mathrm{c}}$ & $1.52 \pm 0.02^{\mathrm{b}}$ & $9.26 \pm 0.52^{\mathrm{e}}$ \\
\hline V & $72.76 \pm 1.97^{\mathrm{e}}$ & $1.37 \pm 0.07^{\mathrm{a}}$ & $8.77 \pm 0.75^{\mathrm{d}}$ \\
\hline
\end{tabular}

${ }^{\mathrm{a}}$ Means in columns followed by the same letters are not significantly different at $\mathrm{p}<0.05$; values represent mean $\pm S D, n=4$.

\subsection{Optimum Stage of Harvesting}

Pulp to peel ratio coupled with total soluble sugars are the most important parameters for harvesting. It increases with more maturity/ripeness and indicates differential changes in moisture content of peel and pulp (Adao and 
Gloria, 2005). With increase in pulp to peel ratio or in other words the more is the maturity the more will be the total soluble sugars which is unsuitable for culinary purpose. In the present study, $50 \mathrm{DAE}$ (stage III) is considered to be the optimum stage of harvesting (Table 10) because from this stage onwards there was more breakdown of starch and in turn more total soluble sugars were obtained and thereafter sharp increase in total soluble sugars at stage IV and V compared to the earlier stages. Therefore from culinary standpoint, $50 \mathrm{DAE}$ (stage III) is the optimum stage for harvesting of Musa ABB.

Table 10. Pulp to peel ratio vis-a-vis total soluble sugars

\begin{tabular}{|c|c|c|}
\hline Stage & Pulp to peel ratio $(\mathrm{g} / 100 \mathrm{~g})$ & Total soluble sugars $(\mathrm{g} / 100 \mathrm{~g})$ \\
\hline I & $1.23 \pm 0.75^{\mathrm{a}}$ & $0.64 \pm 0.03^{\mathrm{a}}$ \\
\hline II & $1.69 \pm 0.94^{\mathrm{b}}$ & $0.72 \pm 0.05^{\mathrm{b}}$ \\
\hline III & $2.01 \pm 0.95^{\mathrm{c}}$ & $1.35 \pm 0.03^{\mathrm{c}}$ \\
\hline IV & $2.11 \pm 0.88^{\mathrm{c}}$ & $2.01 \pm 0.06^{\mathrm{d}}$ \\
\hline V & $2.15 \pm 0.92^{\mathrm{c}}$ & $4.65 \pm 0.97^{\mathrm{e}}$ \\
\hline
\end{tabular}

${ }^{\mathrm{a}}$ Means in columns followed by the same letters are not significantly different at $\mathrm{p}<0.05$; values represent mean $\pm \mathrm{SD}, \mathrm{n}=4$.

\section{Conclusions}

The present study reveals that the nutritional compositions are affected by various growth stages of culinary banana Musa ABB. Pulp to peel ratio and total soluble sugars suggest that $50 \mathrm{DAE}$ is the optimum stage of harvesting. The culinary banana Musa ABB has potential applications of developing numbers of value added products. For instance, the antioxidant activity makes itan excellent ingredient for developing products like cookies, biscuits, bread etc. Furthermore, increased accumulation of starch renders mature tissue a potential source for commercial starch extraction and also presence of considerable amount of amylose allows for developing products which can be subjected to high temperature.

\section{Acknowledgements}

Financial support received from Ministry of Defence, GoI, New Delhi is duly acknowledged. The authors are also grateful to Dr. T. Longvah and Dr. R. Ananthan of Food Chemistry Division, National Institute of Nutrition, Hyderabad, A.P., India for their help.

\section{References}

[1] Adeyemi, O.S. and Oladiji, A.T. Compositional changes in banana (Musa sp) fruits during ripening. African Journal of Biotechnology, 8 (5), 858-859, 2009.

[2] Adao, C.R. and Gloria, A.B.M. Bioactive amines and carbohydrate changes during ripening of 'Prata' banana (Musa acuminate X M. balbisiana). Food Chemistry, 90 (4), 705-711, 2005

[3] Anhwange, B.A. Chemical composition of Musasapientum (banana) peels. Journal of Food Technology, 6 (6), 263-268, 2008.

[4] A.O.A.C. Association of Official Analytical Chemists Official methods of analysis of the Association of Official Analytical Chemists. 18th ed. AOAC International, Washington, DC, 2010.

[5] Bainbridge, Z., Tomlins, K. and Wetby, A. Laboratory methods. In: Bainbridge Z, Tomlins $\mathrm{K}$ and Wetby A (ed). Methods for assessing quality characteristics of non-grain starch staples, Part 3. Natural Resources Institute, Chatham, UK, 1996, 27-29.

[6] Bayfield, R.F. and Cole, E.R. Colorimetric determination of Vitamin A with Trichloroacetic acid. In: McCormick DB and
Wright LD (ed.) Methods in Enzymology, Part F, Vitamins and coenzymes. Academic Press, NY, 1980, 189-95.

[7] Brand-Williams, W., Cuvelier, M.E. andBerset, C. Use of a free radical method to evaluate antioxidant activity. LWT-Food Science and Technology, 28 (1), 25-30, 1995.

[8] Charles, L.A., Sriroth, K. and Huang, T-C. Proximate composition, mineral contents, hydrogen cyanide and phytic acid of 5 cassava genotypes. Food Chemistry, 92 (4), 615 - 620, 2005.

[9] Cheirsilp, B. and Umsakul, K. Processing of banana based wine products using pectinase and alpha-amylase. Journal of Food Processing Engineering, 31 (1), 78-90, 2008.

[10] Deka, S. C. and Harmine, Z. Variation in biochemical constituents of banana fruit CV: Borjahaji (AAA) at different stages of development. Annals of Agricultural Bioresearch, 2, 71-75, 1997.

[11] Doymaz, I. Evaluation of mathematical models for prediction of thin-layer drying of banana slices. International Journal of Food Properties, 13 (3), 486-497, 2010.

[12] Dubois, M., Gilles, K.A., Hamilton, J.K., Rebers, P.A. and Smith, F. Colorimetric method for determinations of sugar and related substances. Analytical Chemistry, 28 (3), 350-356, 1956.

[13] Egbebi, A.O. and Bademosi, T.A. Chemical compositions of ripe and unripe banana and plantain. International Journal of Tropical Medicine and Public Health, 1 (1), 1-5, 2012.

[14] Emaga, T.H., Robert, C., Ronkart, S.N., Wathelet, B. and Paquot, M. Dietary fibre components and pectin chemical features of peels during ripening in banana and plantain varieties. Bioresource Technology, 99 (10), 4346-4354, 2008.

[15] Ganapathi, T.R., Suprasanna, P.S., Bapat, V.A., Kulkarni, V.M. and Rao, P.S. Somatic embryogenesis and plant regeneration from male flower buds of banana. Current Science, 76, 1128-1231, 1999.

[16] Garg, A.N., Kumar, A., Maheshwari, G. and Sharma, S. Isotope dilution analysis for the determination of zinc in blood samples of diabetic patients. Journal of Radioanalalytical and Nuclear Chemistry, 263 (1), 39-43, 2005.

[17] Goswami, B. and Borthakur, A. Chemical and biochemical aspects of developing culinary banana (Musa ABB) 'Kachkal'. Food Chemistry, 55 (2), 169-172, 1996.

[18] Gross, J. Pigments in vegetables: Chlorophylls and carotenoid. Van Nostrand Reinhold, New York, 1991.

[19] Hodge, J.E. and Hofreiter, B.T. Carbohydrates. In: Whistler RL and Miller JNB (ed). Methods in carbohydrate chemistry, Academic Press, New York, 1962, 17-22.

[20] Kanazawa, K. and Sakakibara, H. High content of a dopamine, a strong antioxidant, in Cavendish banana. Journal of Agricultural and Food Chemistry, 48 (3), 844-848, 2000.

[21] Khawas, P., Das, A.J., Dash, K.K. and Deka, S.C. Thin-layer drying characteristics of Kachkal banana peel (Musa ABB) of Assam, India. International Food Research Journal, 21 (3), 975982, 2014.

[22] Komolka, P., Gorecka, D. and Dziedzic, K. The effect of thermal processing of cruciferous vegetables on their content of dietary fiber and its fractions. ACTA Scientiarum Polonorum Technologia Alimentaria, 11 (4), 347-354, 2012.

[23] Kudachikar, V.B., Kulkarni, S.G., Prakash, M.N.K., Vasanta, M.S., Prasad, A.B., and Ramana, K.V.R. Developmental physiology and maturation studies of banana var 'Elakkibale'. Journal of Food Science and Technology, 41 (2), 135-138, 2004.

[24] Lohani, S., Trivedi, P.K. and Nath, P. Changes in activities of cell wall hydrolases during ethylene-induced ripening in banana: Effect of 1-MCP, ABA and IAA. Postharvest Biology and Technology, 31 (2), 119-126, 2004.

[25] Luddy, F.E., Breadford, R.A., Herb, S.F. and Paul, M. A rapid quantitative procedure for the preparation of methyl esters of butter, fat and other fats. Journal of American Oil Chemists' Society, 45 (8), 549-552, 1968.

[26] Malick, C.P. and Singh, M.B. Plant Enzymology and Histoenzymology $4^{\text {th }}$ ed. Kalyani Publishers, New Delhi, 1980.

[27] Marriott, J., Robinson, M. and Karikari, S.K. Starch and sugar transformation during the ripening of plantains and bananas. Journal of the Science of Food and Agriculture, 32 (10), 10211026, 1981.

[28] Maynard, A. J. Methods in food analysis. Academic Press, New York, 1970.

[29] Mendoza, E.M.T., Laurena, A.C., Rodriguez, F.M., Samonte, J.L., Mabesa, L.B. and Uritani, I. Polyphenols in cooking banana changes during ripening and cooking and relation to Astringency. Philippine Journal of Crop Science, 17 (3), 155-161, 1992.

[30] Mohammadi, A., Rafiee, S., Emam-Djomeh, Z. and Keyhani, A. Kinetic models for colour changes in kiwifruit slices during hot air 
drying. World Journal of Agricultural Science, 4 (3), 376-383, 2008.

[31] Moneruzzaman, K.M., Hossain, A.B.M.S., Sani, W. and Saifuddin, M. Effect of stages of maturity and ripening conditions on the biochemical characteristics of tomato. American Journal of Biochemistry and Biotechnology, 4 (4), 336-344, 2008.

[32] Naozuka, J., Vieira, C.E., Nascimento, N.A. and Oliveira, V.P. Elemental analysis of nuts and seeds by axially viewed ICP OES. Food Chemistry, 124 (4), 1667-1672, 2011.

[33] Offem, J.O. and Njoku, P.C. Mineral distribution in the fruits of the plantain plant (Musa paradisiaca) in relation to mode and degree of maturation. Food Chemistry, 48 (1), 63-68, 1993.

[34] Ogazi, P.O. Plantain: Production, processing and utilization. Paman and Associates Publishers, Okigwe, Nigeria, 1996.

[35] Onwuka, G.I. and Onwuka, N.D. The effects of ripening on the functional properties of plantain and plantain based cake. International Journal of Food Properties, 8 (2), 347-353, 2005.

[36] Punna, R. and Paruchuri, U.R. Effect of maturity and processing on total, insoluble and soluble dietary fiber contents of Indian green leafy vegetables. International Journal of Food Science and Nutrition, 55 (7), 561-567, 2004.

[37] Ramadan, M.F. and Morsel, J.T. Neutral lipids classes of black cumin (Nigellasativa L.) seed oils. European Food Research and Technology, 214 (3), 202-206, 2002.

[38] Ranganna, S. Handbook of analysis and quality control for fruit and vegetable products. 2nd ed. Tata McGraw-Hill Publishing Ltd., New Delhi, India, 2008.

[39] Rop, O., Sochor, J., Jurikova, T., Zitka, O., Skutkova, H., Mlcek, J., Salas, P., Krska, B., Babula, P., Adam, V., Kramarova, D. Beklova, M., Provaznik, I., and Kizek, R. Effect of five different stages of ripening on chemical compounds in medlar (Mespilusgermanica L.). Molecules, 16 (1), 74-91, 2010.

[40] Sadasivam, S. and Manickam, A. Biochemical methods. 3rd edn. New Age International Publishers, New Delhi, India, 2008.

[41] Sakyi-Dawson, E., Asamoah-Bonti, P. and Annor, G.A. Biochemical changes in new plantain and cooking banana hybrids at various stages of ripening. Journal ofthe Science of Food Agriculture, 88 (15), 2724-2729, 2008.
[42] Schanderi, S.H. Method in food analysis. Academic Press, New York, 1970

[43] Seenappa, M., Laswai, H.S.M. and Ferando, S.P.F. Availability of L-ascorbic acid in Tanzanian banana. Journal of Food Science and Technology, 23 (5), 293-295, 1986.

[44] Segung, K. and Kader, A.A. Preharvest and postharvest factors influencing vitamin $\mathrm{C}$ content of horticultural crops. Postharvest Biology and Technology, 20 (3), 207-220, 2000.

[45] Simopoulos, A.P. Essential fatty acids in health and chronic disease. The American Journal of Clinical Nutrition, 70 (3), 560 S-569 S, 1999.

[46] Soltani, M., Alimardan,i R., Omid, M. and Karaj, I. Changes in physico-mechanical properties of banana fruit during ripening treatment. Journal of American Science, 7 (5), 14-19, 2011.

[47] Somogyi, M. Notes on sugar determination. Journal of Biological Chemistry, 195, 19-23, 1952.

[48] Sorrequieta, A., Abriata, L.A., Boggio, S.B. and Vall, E.M. Offthe-vine ripening of tomato fruit causes alteration in the primary metabolite composition. Metabolites, 3 (4), 967-978, 2013.

[49] Stafford, H.A. Differences between lignin like polymer formed by peroxidation of eugenol and ferulic acid in leaf section of Phleum. Plant Physiology, 35 (1), 108-114, 1960.

[50] Stover, R.H. and Simmonds, N.W. Classification of banana cultivars. In: Stover RH and Simmonds NW (ed.) Bananas, $3^{\text {rd }}$ edn. Wiley, New York, 1987, 97-103.

[51] Ukhun, M.E. Production of instant plantain flour, sensory evaluation and physico-chemical changes during storage. Food Chemistry, 42 (3), 287-299, 1991.

[52] Wheeler, E.L. and Ferrel, R.E. A method for phytic acid determinations in wheat and wheat fractions. Cereal Chemistry, 48 (3), 312-320, 1971.

[53] Yang, S.F. and Hoffman, N.E. Ethylene biosynthesis and its regulation in higher plants. Annual Review of Plant Physiology, 35, 155-189, 1984.

[54] Zuhair, R.A., Aminah, A., Sahilah, A.M. and Eqbal, D. Antioxidant activity and physicochemical properties changes of papaya (Carica papaya L. cv. Hong Kong) during different ripening stage. International Food Research Journal, 20 (4), 1653-1659, 2013. 